\title{
Surface water quality assessment with reference to trace metals in River Mahanadi and its tributaries, India
}

\author{
Jakir Hussain $^{1}$ ([) Arati Dubey ${ }^{2} \cdot$ Ikbal Hussain $^{3} \cdot$ Mohd. Arif $^{4} \cdot$ Ajay Shankar $^{5}(\mathbb{C}$
}

Received: 6 January 2019 / Accepted: 2 July 2020 / Published online: 14 July 2020

(c) The Author(s) 2020

\begin{abstract}
Trace elements (As, $\mathrm{Cr}, \mathrm{Cu}, \mathrm{Cd}, \mathrm{Hg}, \mathrm{Fe}, \mathrm{Pb}, \mathrm{Ni}$, and $\mathrm{Zn}$ ) in surface water of Mahanadi River and its tributaries were measured in order to investigate their geospatial metal distribution and extent of contamination. The study was designed to make water quality comparisons with local and global average values. As the river and its contributing tributaries flow through a diverse geologic, topographic, hydrologic, and industrial region, a large catchment area comprising 17 inter-distant water quality sites was chosen. A total of seventy-five water samples were analyzed for the concentration of trace metals in dissolved phases using atomic absorption spectrophotometer. The contamination factor data suggest that several metals had higher concentrations than acceptable and permissible limits prescribed by World Health Organization. Principal component analysis reveals the relationships between metal groups, viz. $\mathrm{Ni}, \mathrm{Cr}, \mathrm{Cu}$, and $\mathrm{Fe}$, and $\mathrm{Hg}, \mathrm{Pb}$, and $\mathrm{Cd}$, and $\mathrm{Zn}$ and $\mathrm{As}$. It indicates a difference in the sources of their origin. Further, Pearson's coefficient analysis revealed a strong and specific intermetal relationships among studied metals. The statistical analysis points toward various industrial wastes and municipal wastes as primary contributing factors for most of the excess dissolved metals in the Mahanadi River.
\end{abstract}

Keywords Mahanadi River · Tributaries · Water quality $\cdot$ Trace metals $\cdot$ PCA analysis $\cdot$ Pearson's coefficient

\section{Introduction}

The quality of water plays an important role in environmental monitoring. In present days, it is a matter of serious concern for the health of both human and animals. It measures the condition of water relative to the requirements of one or more biotic species and human need or purpose. The

Electronic supplementary material The online version of this article (https://doi.org/10.1007/s13201-020-01277-1) contains supplementary material, which is available to authorized users.

Jakir Hussain

drjakirhussain@gmail.com

1 National River Water Quality Laboratory, Central Water Commission, Ministry of Jal Shakti, New Delhi, India

2 Independent Researcher, Vijay Enclave, New Delhi, India

3 Public Health Engineering Department, District Laboratory, Bhilwara, Rajasthan, India

4 Department of Chemistry, Banasthali University, Banasthali, Rajasthan, India

5 Department of Chemistry, Indira Gandhi National Tribal University, Amarkantak, Madhya Pradesh 484887, India quality of river water depends on a number of interrelated factors such as geology, climate, topography, biological processes, and land use. Trace metals are tenacious environmental pollutants which enter in the river from a variety of natural as well as anthropogenic sources (Bem et al. 2003). Usually, trace metals are derived from point sources, such as smelting and mining, disposal of partially treated and completely untreated effluents, discharged metal chelates from different industries, and indiscriminate use of heavy metal-containing fertilizer and unutilized pesticides from agricultural fields. The practice of discharging of untreated domestic and small-scale industries into the water bodies leads to the increased level of concentration of the metals in the rivers passing through urban areas (Khadse et al. 2008). A number of studies on Mahanadi River basin mainly dealt with heavy metal ions in water and sediments (Asokan and Dutta 2008; Sundaray et al. 2012). Other works are related to the river geochemistry (Chakrapani and Subramanian 1990), multivariate statistical techniques being employed for the evaluating spatial and temporal variations in water quality of the Mahanadi River-estuarine system (Sundaray et al. 2006), river water quality for agricultural purposes (Sundaray et al. 2009), potential risk of heavy metals concentration 
on aquatic biota (Mohanty and Samanta 2016), and analysis of water resources in the Mahanadi River basin (Asokan and Dutta 2008). In addition, one prior study (Sundaray et al. 2012) involved quantification of dissolved metals in water which was limited to heavy metals only. The current study is different from previous reports. In this study, the river tributaries are considered in addition to main stream channel and focused on a broader set of trace metals in the surface water. To this end, principal component analysis (PCA) and Pearson correlation coefficient analysis techniques were employed in this study. PCA and Pearson correlation coefficient analysis are multivariate techniques used to particularly estimating the large number and complex chemical datasets. PCA is extensively used to summarize the data with many variables by a smaller set of derived variables and Pearson correlation coefficient used to determine the degree to which two variables are related. In recent times, PCA and correlation coefficient techniques have been widely in use for environmental studies on measurement and monitoring (Ouyang 2005; Shrestha and Kazama 2007; Olsen et al. 2012).

The present study estimates the metal pollution level in the Mahanadi River and its tributaries in India; this is the routine work for the river water quality monitoring system. Regular sampling and measuring of water quality were done on a monthly basis by the Central Water Commission (CWC), India. The characteristics of water vary apparently periodically with difference in different watersheds at different monitoring stations. Even, most water quality data fluctuate under the influences of season and pollution, so routine sampling gives us the present status of the elements at these locations. The Mahanadi River is one of the major inter-state east flowing rivers in peninsular India. The river provides the water for irrigation, domestic, and industrial purposes, so the quality of water is a matter of concern for the future use. In this study, the main objectives are: to assess spatial and temporal distribution of concentration of heavy metals and possible sources in the river water. Results may provide the evidence related to water pollution into the catchment area.

\section{Materials and methods}

\section{River catchments}

The Mahanadi basin extends over an area of $141,589 \mathrm{~km}^{2}$ which is nearly $4.3 \%$ of the total geographical area of India. It lies between east longitudes 8030-8650 and north latitudes 1921-2335. The Mahanadi River is among the major rivers flowing from west to east and finally draining into the Bay of Bengal. The major contributing tributaries are the Hasdeo, the Seonath, the Mand, the Ib, the Bhadar, the Jonk, the Ong, and the Tel. The annual runoff of the river water is $50 \times 109 \mathrm{~m}^{3}$ with a peak discharge of $44,740 \mathrm{~m}^{3} \mathrm{~s}^{-1}$ (Chakrapani and Subramanian 1990; Sundaray et al. 2006). The river commences in southeastern region of Chhattisgarh (in central India) as a small stream draining the eastern part of the plain region. As the river progresses, it rises in a pool at a height of $442 \mathrm{~m}$, which is $6 \mathrm{~km}$ from Pharsiya village (of Nagri town) in the state capital, Raipur of Chhattisgarh. The village population is mainly dependent on agriculture for its income. For initial $\sim 56 \mathrm{~km}$, the river turns to west passing through scattered hills which encompasses a shallow valley where there is negligible influence of any industrial development. Four small streams join the river in its way near Kanker, and then, it sharply takes northwestern course. The Kanker region has agriculture as the mainstay of people in the district. This region is mineral rich specifically in iron ore, quartzite, and garnet deposits. After flowing through a length of about $113 \mathrm{~km}$ without changing its direction, the Pairi River at Rajim joins at its right. The socio-economic aspects of the local population of Rajim are significantly dependent on tourism apart from agriculture and few industries like steel and rice mill also found at this place. The first major tributary Seonath joins the Mahanadi in Bilaspur District about $13 \mathrm{~km}$ above Sheorinarayan. The district can be categorized as highly developed compared to previous locations of the river. After the sangam of rivers of approximately equal width, the Mahanadi River turns east covering a distance of $\sim 138 \mathrm{~km}$. The tributary Jonk joins from the right at Sheorinarayan town. After traversing about $17 \mathrm{~km}$ further down near to Mahuadih, the Hasdeo tributary adjoins it from the left. Later on, it is joined at Chandarpur by the Mand River from the left. The Mahuadih and Chandarpur locations have significant farming activities in the region. After covering $28 \mathrm{~km}$, Mahanadi leaves Chhattisgarh State and enters next State Orissa. Herein, the Ib River joins from the left near Bagra. The region has a large area of forests with low human activities. Further, the river flows into the rocky beds of Hirakud dam which is located across Mahanadi $10 \mathrm{~km}$ from Sambalpur City. The height and length of dam are $61 \mathrm{~m}$ and $4.8 \mathrm{~km}$, respectively. Hirakud dam shows largescale socioeconomic impacts, providing water and energy resources to populations that are in crisis. The dam plays important role in flood management, irrigation, hydropower production, and navigation. The City Sambalpur has number of industries and some minerals like bauxite, coal, and dolomite. Below this city, the river takes southern turn after passing through a number of rapids and subsequently gets bifurcated into two channels near Charpali village and then reunites again near Dhama. For about $11 \mathrm{~km}$ below Dhama, the Mahanadi first flows southerly and then southeasterly for a $\sim 45 \mathrm{~km}$ distance and it reaches Sonepur town. About $11 \mathrm{~km}$ upstream of Sonepur, the Ong River falls into the Mahanadi from its right. The second biggest 
tributary, the Tel joins after taking a gradual turn to the southeast near Sonepur where the chains of Eastern Ghats mountains begin. The river again divides into two arms at town Haudh and beyond Athmalik, the valley narrows down sharply and for $\sim 23 \mathrm{~km}$, and the river passes through the extremely narrow Satkosis Gorge. The water quality station, Tikarpara village, is nearly $6 \mathrm{~km}$ below the start of the narrowest pass. Tikarpara is a major tourist attraction located in the basin. As the gorge ends at Baramul, the river crosses the Eastern Ghats. The valley of the Mahanadi between villages Baramul and Baideshwar is flat with scattered hillocks. The river widens again below Baramul thereby attaining a width of $\sim 1.6 \mathrm{~km}$. It flows through the Kaimundi gorge near Pathpur. Below this gorge, the river widens up again and turns left, to finally emerge into the Naraj delta, $11 \mathrm{~km}$ west of the state capital, Cuttack. The river splits into two channels below this delta, and after splitting into numerous watery branches, the Mahanadi River finally debouches into the Bay of Bengal, near to False Point. The study river has a total length of $\sim 851 \mathrm{~km}$ out of which $357 \mathrm{~km}$ is in Chhattisgarh State and the rest of it in Orissa (Jain et al. 2007). The study area with the required basic geographical details and stations are shown in Fig. 1.

\section{Sampling methodology}

The grab samples were collected from the Mahanadi River and its tributaries at a depth of about $0.3 \mathrm{~m}$ from the river surface. The samples were collected during the months of September 2011; February, June, and October 2012; March and August 2013. Seventeen sampling stations were chosen to assess the impact of heavy metal concentrations for Mahanadi River and its tributaries due to domestic, industrial effluents, and mining activities in the basin. The hydrological characteristics of study locations, viz. longitude, latitude, catchment area, and their respective tributaries, are summarized in Table 1. The sampling was done on a boat fitted with an outboard engine of appropriate power. The working conditions of the outboard engine were chosen to ensure that the collected samples represented the main flow of the river. The high-density polyethylene sample bottles were soaked in $10 \% \mathrm{HNO}_{3}$ for $24 \mathrm{~h}$ and rinsed several times with double distilled water (DW) prior to use. For quantification

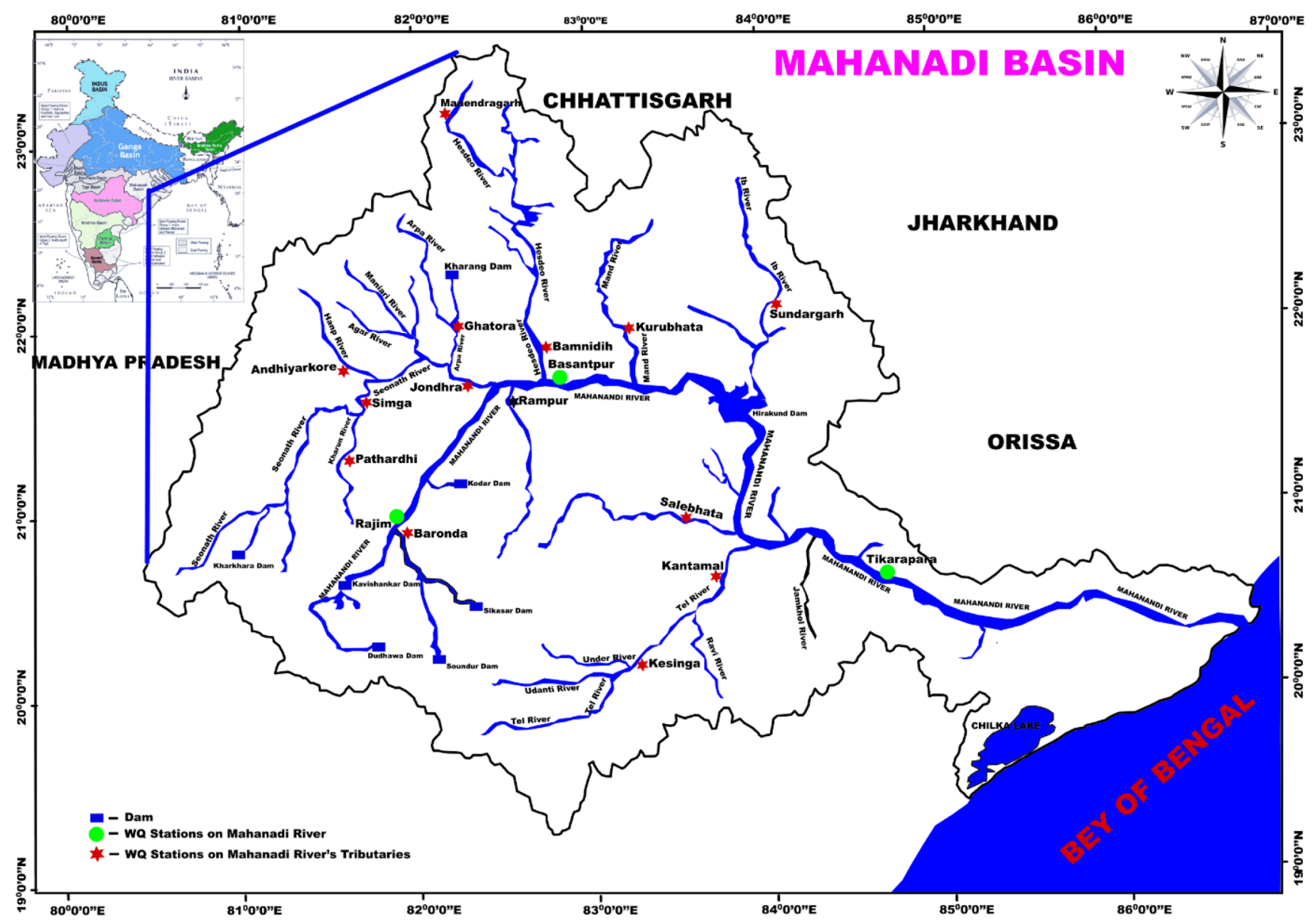

Fig. 1 Map showing detailed view of Mahanadi River, its tributaries, and sampling sites 
Table 1 Hydrological characteristics of the WQ stations across Mahanadi River

\begin{tabular}{|c|c|c|c|c|c|c|c|}
\hline Site & Name of WQ site & Name of river/tributary/subtributary & $\begin{array}{l}\text { Catchment } \\
\text { area }\left(\mathrm{km}^{2}\right)\end{array}$ & Latitude & Longitude & District & State \\
\hline $\mathrm{S} 1$ & Rajim & Mahanadi & 8760 & $20^{\circ} 58^{\prime} 25^{\prime \prime}$ & $81^{\circ} 52^{\prime} 42^{\prime \prime}$ & Raipur & Chhattisgarh \\
\hline $\mathrm{S} 2$ & Baronda & Mahanadi/Pairi & 3225 & $20^{\circ} 54^{\prime} 45^{\prime \prime}$ & $81^{\circ} 53^{\prime} 10^{\prime \prime}$ & Raipur & Chhattisgarh \\
\hline $\mathrm{S} 3$ & Pathardihi & Mahanadi/Seonath/Kharun & 2511 & $21^{\circ} 20^{\prime} 28^{\prime \prime}$ & $81^{\circ} 35^{\prime} 38^{\prime \prime}$ & Raipur & Chhattisgarh \\
\hline S4 & Simga & Mahanadi/Seonath/Kharun & 30,761 & $21^{\circ} 37^{\prime} 51^{\prime \prime}$ & $81^{\circ} 41^{\prime} 16^{\prime \prime}$ & Raipur & Chhattisgarh \\
\hline S5 & Andhiyar kore & Mahanadi/Seonath/Hamp & 2210 & $21^{\circ} 49^{\prime} 54^{\prime \prime}$ & $81^{\circ} 36^{\prime} 21^{\prime \prime}$ & Durg & Chhattisgarh \\
\hline S6 & Ghatora & Mahanadi/Seonath/Arpa & 3035 & $22^{\circ} 03^{\prime} 24^{\prime \prime}$ & $82^{\circ} 13^{\prime} 10^{\prime \prime}$ & Bilaspur & Chhattisgarh \\
\hline S7 & Jondhra & Mahanadi/Seonath & 29,645 & $21^{\circ} 42^{\prime} 57^{\prime \prime}$ & $82^{\circ} 20^{\prime} 50^{\prime \prime}$ & Bilaspur & Chhattisgarh \\
\hline S8 & Rampur & Mahanadi/Jonk & 2920 & $21^{\circ} 39^{\prime} 06^{\prime \prime}$ & $82^{\circ} 31^{\prime} 02^{\prime \prime}$ & Raipur & Chhattisgarh \\
\hline S9 & Manendragarh & Mahanadi/Hasdeo & 1100 & $23^{\circ} 12^{\prime} 13^{\prime \prime}$ & $82^{\circ} 13^{\prime} 02^{\prime \prime}$ & Koriya & Chhattisgarh \\
\hline $\mathrm{S} 10$ & Bamnidih & Mahanadi/Hasdeo & 9730 & $21^{\circ} 53^{\prime} 55^{\prime \prime}$ & $82^{\circ} 42^{\prime} 42^{\prime \prime}$ & Janjgir-champa & Chhattisgarh \\
\hline $\mathrm{S} 11$ & Basantpur & Mahanadi & 57,780 & $21^{\circ} 43^{\prime} 36^{\prime \prime}$ & $82^{\circ} 47^{\prime} 17^{\prime \prime}$ & Janjgir-champa & Chhattisgarh \\
\hline $\mathrm{S} 12$ & Kurubhata & Mahanadi/Mand & 4625 & $21^{\circ} 59^{\prime} 11^{\prime \prime}$ & $83^{\circ} 12^{\prime} 15^{\prime \prime}$ & Raigarh & Chhattisgarh \\
\hline $\mathrm{S} 13$ & Sundergarh & Mahanadi/Ib & 5870 & $22^{\circ} 06^{\prime} 55^{\prime \prime}$ & $84^{\circ} 00^{\prime} 40^{\prime \prime}$ & Sundergarh & Orissa \\
\hline $\mathrm{S} 14$ & Salebhata & Mahanadi/Ong & 4650 & $20^{\circ} 59^{\prime} 00^{\prime \prime}$ & $83^{\circ} 32^{\prime} 22^{\prime \prime}$ & Balangir & Odisha \\
\hline $\mathrm{S} 15$ & Kesinga & Mahanadi/Tel & 11,960 & $20^{\circ} 12^{\prime} 14^{\prime \prime}$ & $83^{\circ} 13^{\prime} 23^{\prime \prime}$ & Kalahandi & Odisha \\
\hline S16 & Kantamal & Mahanadi/Tel & 19,600 & $20^{\circ} 39^{\prime} 00^{\prime \prime}$ & $83^{\circ} 43^{\prime} 20^{\prime \prime}$ & Boudh & Odisha \\
\hline S17 & Tikarpara & Mahanadi & 124,450 & $20^{\circ} 35^{\prime} 22^{\prime \prime}$ & $84^{\circ} 47^{\prime} 00^{\prime \prime}$ & Angul & Odisha \\
\hline
\end{tabular}

of metals, $500 \mathrm{~mL}$ of collected water samples was acidified immediately after each sample collection, using $2 \mathrm{~mL}$ of $1: 1$ mixture of conc. $\mathrm{HNO}_{3}$ and $\mathrm{DW}$, and $2 \mathrm{~mL} \mathrm{HCl}$ for arsenic to lower $\mathrm{pH}(<2)$. Thereafter, the samples were stored at $4{ }^{\circ} \mathrm{C}$ in sampling kits and brought to the laboratory for quantitative metal analysis (Singh et al. 2005).

\section{Analytical methods}

The acid digestion of all the samples was performed using $\mathrm{HNO}_{3}$ for minimizing the interference by organic matter prior to estimation of the heavy metals. One liter of each collected water sample was first concentrated on a sandy oven at $80{ }^{\circ} \mathrm{C}$ until the volume reached $50 \mathrm{~mL}$. Then, $4 \mathrm{~mL}$ concentrated sulfuric acid (Merck, 98\%) was added to each sample and digested $3 \mathrm{~min}$. Then, $10 \mathrm{~mL}$ hydrogen peroxide (Merck, 30\%) was added and heated until oxidation was completed. After cooling, each sample was filtered by filter (Whatman filter Merck, $0.45 \mu \mathrm{m}$ ). The filtrate was diluted by deionized water to a final volume of $50 \mathrm{~mL}$. The prepared samples were measured for respective metals by using atomic absorption spectrophotometer (model Agilent 240 FS) with the specific lamps for respective metals. For zinc and iron, flame method is used. Cadmium, copper, chromium, nickel, and lead metals were measured by graphite tube atomizer (GTA) method. For arsenic metal, the vapor generator accessory method was used. All solutions were prepared using Milli-Q deionized water.

For quality control, analytical blanks and certified reference with the known concentrations (5 and $10 \mathrm{ppb}$ for every element) were prepared and analyzed using the same procedures and reagents. The quality control samples were run at an interval of 15 samples, and if the relative differences of any element were more than $20 \%$, the process was stopped and cross-checked. The instrument was calibrated by certified reference material from Merck Germany with known concentration of relevant metals. After analysis of every 10 samples, blank and control standards were analyzed to minimize the error.

\section{Statistical analysis}

In this study, statistical analysis of data was performed by using Origin software 9.0. Pearson correlation was used to determine the relationship between the concentrations of heavy metals in the river water. Prior to the correlation analysis, normality tests on datasets were performed using Kolmogorov-Smirnov (K-S) method. The contour diagrams of all nine heavy metals were drawn by Surfer software 12.1

\section{Results and discussion}

\section{Distribution of concentrations of trace elements in the Mahanadi River and its tributaries}

The distribution patterns of studied trace elements across whole Mahanadi basin are shown by the Box-Whisker plot. A Box-Whisker chart was plotted on a logarithmic scale using concentrations of metals in all measured samples 


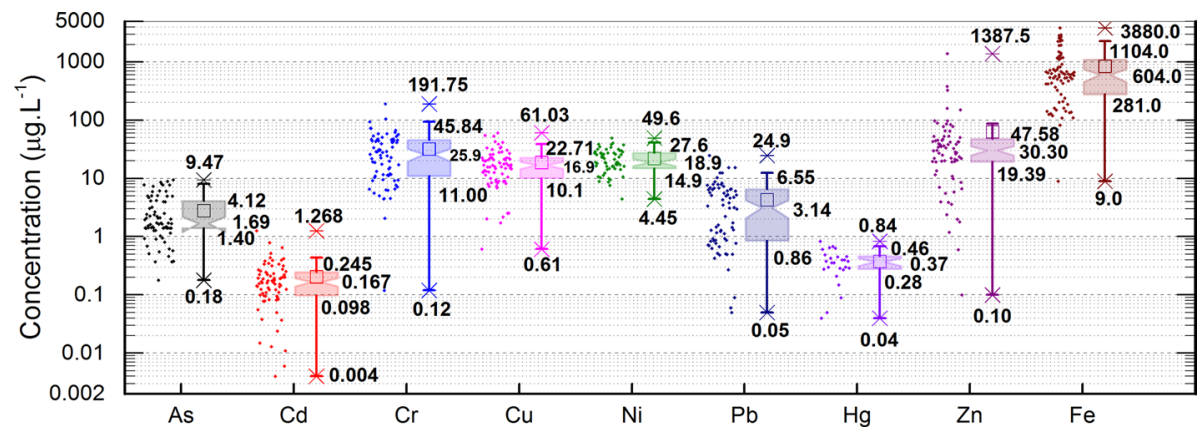

Fig. 2 Box-Whisker plot of concentrations of the metal ions. Dots represents the concentration of respective metals in measured samples. The top and bottom of boxes cover a quartile range from 25 to 75 th percentile. Whiskers in the form of outliers represent the outermost data point falling within upper inner and lower inner fences. The minimum, maximum, lower quartile, upper quartile, and median values are labeled for each metal. $\square, \times$, and - represent the arithmetic mean, minimum or maximum (whichever is applicable), and outliers, respectively

metals. A water quality hotspot analysis was performed by using the water quality standards published by World Health Organization (WHO) (World Health Organization 2011) and Bureau of Indian Standards (BIS) (Bureau of Indian Standard 2012) which is shown in Table 3. Therein, the number of water quality samples exceeding the acceptable limit of trace and toxic metals during the study period are enlisted.

\section{Seasonal variation in trace elements in river water}

$9.000-3880.000 \mu \mathrm{g} / \mathrm{L}$ for Fe. As shown in Fig. 2, Cd, As, $\mathrm{Hg}$, and $\mathrm{Zn}$ had levels below their respective permissible limits. The higher concentration of remaining metals in sampling sites indicated exclusive anthropogenic and geogenic activities. Each whisker encompasses the outlier range of concentrations of respective metals. Except for a few cases, viz. $\mathrm{Cd}, \mathrm{As}, \mathrm{Zn}$, and $\mathrm{Hg}$, the concentration data were found to obey roughly a normal distribution on the linear scale. By visual comparison of median concentration values across the Box-Whisker plots, the relative abundance of all metal ions in whole Mahanadi basin can be arranged in decreasing order: $\mathrm{Fe}>\mathrm{Zn}>\mathrm{Cr}>\mathrm{Ni}>\mathrm{Cu}>\mathrm{Pb}>\mathrm{As}>\mathrm{Hg}>\mathrm{Cd}$. The values of average concentrations of each metal during whole study period in respect of their studied stations were used in contour map representation (Fig. 3).

Further, to see the detailed variation in metal availability across the main river, its tributaries, and sub-tributaries, the maximum, minimum, and average concentrations along with standard deviations are depicted in Table S1.

Note that geographical locations of water quality sites across whole Mahanadi basin are varyingly distributed among its tributaries and sub-tributaries. Thus, to gain a further insight into the bioavailability of studied metals, a separate table showing minimum, maximum, average concentration, and its standard deviation for each station is made in Table 2. A careful look at statistical parameters of Table $\mathrm{S} 1$ and Table 2 suggests an order of difference exists between the concentrations of $\mathrm{Cr}, \mathrm{Zn}$, and $\mathrm{Fe}$ and rest of
The quality of water samples from S1 to S17 was found within the limit for all elements during monsoon season except $\mathrm{Ni}$ and $\mathrm{Fe}$. Probably, it may be due to bulk precipitation of former elements leading to lesser amount in surface water. The worst conditions for $\mathrm{Ni}$ and $\mathrm{Fe}$ at sampling sites along with $\mathrm{Pb}$ (at $\mathrm{S} 9$ ) could be due to anthropogenic activities (World Health Organization 2011) (Bureau of Indian Standard 2012).

The metal concentration during post-monsoon was higher for few elements like $\mathrm{As}, \mathrm{Cr}, \mathrm{Cu}, \mathrm{Pb}, \mathrm{Hg}$, and $\mathrm{Fe}$. This may be primarily due to anthropogenic activities, viz. ongoing coal mining, industrial wastage, sewage effluents, processing of small batteries for lead recovery, and idol immersion. The secondary reason for this observation could be due to geogenic activities. In contrast, $\mathrm{Cd}, \mathrm{Ni}$, and $\mathrm{Zn}$ were found higher during pre-monsoon season. Most probably, it could be due to man-made activities while Ni could have additional contribution from the geogenic sources. A decreasing trend in metal concentrations was found in monsoon and pre-monsoon season as compared to post-monsoon season (Table 4). The metal concentrations in all water samples met the WHO and BIS standard for drinking water quality, with the exception for $\mathrm{Cr}, \mathrm{Cu}, \mathrm{Ni}, \mathrm{Pb}$, and $\mathrm{Fe}$. These metals remain concern for many water quality sites. The $\mathrm{Fe}$ concentration range (151.0-3880.0 $\mu \mathrm{g} / \mathrm{L})$ was found to be polluting for all studied sites round the year. The discharge

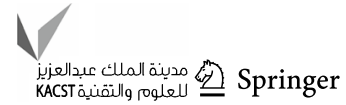



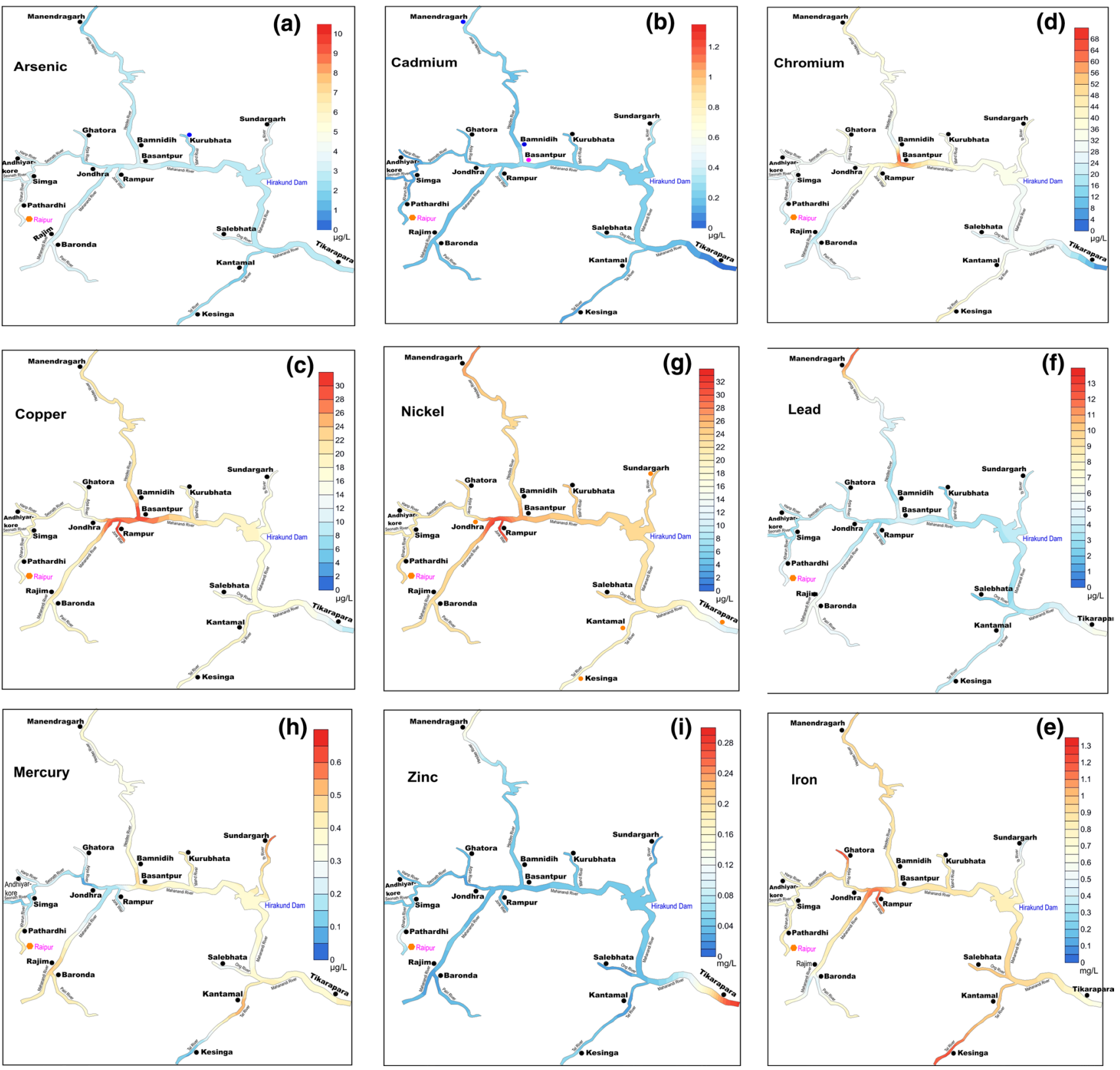

Fig. 3 Contour map diagrams showing the concentration of the specified trace elements a As, b Cd, $\mathbf{c ~ C r , ~} \mathbf{d ~ C u , ~ e ~ N i , ~ f ~ P b , ~} \mathbf{g ~ H g}, \mathbf{h} \mathrm{Zn}$, and i Fe at various water sample locations across Mahanadi River system

of untreated effluents from metal electroplating industries, leachates of soluble iron from the mining of iron ore and urban wastes directly into the nearby sites could have led to this situation. The $\mathrm{Cr}$ and $\mathrm{Ni}$ were also found to be polluting with concentration range $39.570-191.750 \mu \mathrm{g} / \mathrm{L}$ and $39.190-191.750 \mu \mathrm{g} / \mathrm{L}$, respectively. The Cr pollution found at sites S5, S8, S9, S11, S13, S14, S15, and S16 in both monsoon and post-monsoon seasons might be due to geogenic and associated anthropogenic activities, especially mining activities. Similar seasonal behavior was found for Ni for all sites which may be due to point and non-point sources of pollution, waste incinerators, power plants, and metal industries, and it is directly emitted from various industries through discharge on surface waters nearby the sites. The $\mathrm{Cu}$ having range (39.000-61.030) $\mu \mathrm{g} / \mathrm{L}$ was found to be polluting only S8, S11, and S16 during pre-monsoon season and post-monsoon season. This could be due to the geogenic activity as the significant source of pollution. The Mayurbhanj and Sambalpur districts are rich in copper minerals such as chalcopyrite, malachite, azurite, bornite. Also, in a nearby location, Sundergarh (S13) there is a copper manufacturing unit that directly discharges in district. The metal $\mathrm{Pb}$ also 
Table 2 Trace and toxic metal concentration (range, average and standard deviation) across different WQ sites (CWC, 2014)

\begin{tabular}{|c|c|c|c|c|c|c|c|c|c|}
\hline $\begin{array}{l}\text { WQ } \\
\text { site }\end{array}$ & As & $\mathrm{Cd}$ & $\mathrm{Cr}$ & $\mathrm{Cu}$ & $\mathrm{Ni}$ & $\mathrm{Pb}$ & $\mathrm{Hg}$ & $\mathrm{Zn}$ & $\mathrm{Fe}$ \\
\hline \multirow[t]{2}{*}{ S1 } & $2.230 \pm 1.540$ & $0.148 \pm 0.081$ & $10.280 \pm 4.860$ & $24.410 \pm 9.367$ & $24.880 \pm 3.893 .900$ & $5.690 \pm 4.990$ & $0.650 \pm$ (n.a.) & $25.960 \pm 19.200$ & $1065.670 \pm 1082.010$ \\
\hline & $1.270-4.010$ & $0.080-0.240$ & $5.030-14.620$ & $16.020-34.520$ & $22.120-27.630$ & $0.500-10.450$ & $0.650-0.650$ & $10.900-47.580$ & $281.000-2300.000$ \\
\hline \multirow[t]{2}{*}{$\mathrm{S} 2$} & $4.220 \pm 2.430$ & $0.180 \pm 0.140$ & $26.830 \pm 17.360$ & $16.150 \pm 6.600$ & $21.840 \pm 4.120$ & $5.950 \pm 4.030$ & $0.400 \pm$ (n.a.) & $26.120 \pm 9.650$ & $358.330 \pm 164.340$ \\
\hline & $1.470-6.080$ & $0.080-0.340$ & $11.800-45.840$ & $8.900-21.820$ & $18.930-24.750$ & $3.100-8.800$ & $0.400-0.400$ & $19.730-37.220$ & $210.000-535.000$ \\
\hline \multirow[t]{2}{*}{ S3 } & $4.790 \pm 3.670$ & $0.150 \pm 0.040$ & $23.920 \pm 16.050$ & $12.940 \pm 4.280$ & $23.150 \pm 6.390$ & $4.900 \pm 4.250$ & $0.380 \pm($ n.a. $)$ & $131.840 \pm 169.630$ & $817.330 \pm 386.250$ \\
\hline & $2.280-9.004$ & $0.107-0.192$ & $11.000-41.890$ & $8.030-15.860$ & $18.630-27.670$ & $0.060-8.010$ & $0.380-0.380$ & $28.040-327.600$ & $556.000-1261.000$ \\
\hline \multirow[t]{2}{*}{ S4 } & $3.190 \pm 2.840$ & $0.130 \pm 0.084$ & $27.830 \pm 13.064$ & $18.056 \pm 9.350$ & $20.720 \pm 5.770$ & $2.660 \pm 2.300$ & $0.090 \pm($ n.a. $)$ & $39.760 \pm 29.610$ & $718.000 \pm 528.850$ \\
\hline & $1.410-7.380$ & $0.050-0.250$ & $15.440-44.580$ & $8.550-28.600$ & $14.670-26.170$ & $1.180-5.310$ & $0.090-0.090$ & $10.000-78.500$ & $163.000-1432.000$ \\
\hline \multirow[t]{2}{*}{ S5 } & $3.090 \pm 2.050$ & $0.134 \pm 0.141$ & $30.470 \pm 23.106$ & $19.170 \pm 15.330$ & $19.610 \pm 6.560$ & $4.225 \pm 6.380$ & $0.300 \pm$ (n.a.) & $19.680 \pm 14.690$ & $617.800 \pm 549.740$ \\
\hline & $0.810-5.970$ & $0.020-0.380$ & $4.560-59.250$ & $2.190-41.880$ & $11.350-26.100$ & $0.270-15.350$ & $0.300-0.300$ & $4.000-35.400$ & $143.000-1513.000$ \\
\hline \multirow[t]{2}{*}{ S6 } & $2.689 \pm 2.013$ & $0.160 \pm 0.026$ & $40.160 \pm 4.596$ & $17.010 \pm 6.880$ & $23.005 \pm 6.190$ & $3.705 \pm 4.023$ & $0.270 \pm($ n.a. $)$ & $30.760 \pm 6.790$ & $1223.670 \pm 1199.800$ \\
\hline & $1.420-5.010$ & $0.140-0.190$ & $34.890-43.340$ & $9.070-21.050$ & $18.630-27.380$ & $0.860-6.550$ & $0.270-0.270$ & $26.570-38.600$ & $441.000-2605.000$ \\
\hline \multirow[t]{2}{*}{ S7 } & $2.349 \pm 1.530$ & $0.170 \pm 0.145$ & $29.510 \pm 16.530$ & $13.950 \pm 7.180$ & $20.315 \pm 4.460$ & $3.970 \pm 3.260$ & $0.050 \pm$ (n.a.) & $24.760 \pm 16.080$ & $806.330 \pm 363.900$ \\
\hline & $1.450-4.120$ & $0.078-0.340$ & $13.300-46.340$ & $7.320-21.570$ & $17.160-23.470$ & $0.430-6.840$ & $0.050-0.050$ & $7.100-38.570$ & $477.000-1197.000$ \\
\hline \multirow[t]{2}{*}{ S8 } & $3.006 \pm 3.403$ & $0.230 \pm 0.090$ & $37.450 \pm 15.710$ & $30.430 \pm 15.860$ & $32.570 \pm 32.570$ & $2.680 \pm$ & $0.150 \pm($ & $48.500=$ & 35.210 \\
\hline & $0.920-8.090$ & $0.130-0.350$ & $22.470-58.520$ & $18.760-53.450$ & $16.390-49.610$ & $0.680-6.880$ & $0.150-0.150$ & $20.300-65.700$ & $611.000-2735.000$ \\
\hline \multirow[t]{2}{*}{ S9 } & $1.504 \pm 0.160$ & $0.300 \pm 0.100$ & $47.170 \pm 5.520$ & $22.110 \pm 5.120$ & $28.045 \pm 3.076$ & $13.490 \pm 12.520$ & $0.380 \pm$ (n.a.) & $177.270 \pm 180.260$ & $967.330 \pm 847.260$ \\
\hline & $1.400-1.690$ & $0.220-0.420$ & $41.710-52.750$ & $16.930-27.170$ & $25.870-30.220$ & $0.090-24.900$ & $0.380-0.380$ & $50.580-383.600$ & $370.000-1937.000$ \\
\hline \multirow[t]{2}{*}{ S10 } & $2.640 \pm 2.670$ & $0.150 \pm 0.080$ & $21.430 \pm 10.230$ & $21.430 \pm 11.760$ & $21.380 \pm 11.260$ & $2.750 \pm 3.070$ & $0.360 \pm 0.090$ & $46.430 \pm 31.800$ & $801.170 \pm 619.370$ \\
\hline & $0.370-7.810$ & $0.004-0.230$ & $6.260-30.750$ & $1.730-33.600$ & $12.390-41.000$ & $0.510-7.950$ & $0.29-0.430$ & $3.600-84.640$ & $163.000-1964.000$ \\
\hline \multirow[t]{2}{*}{ S11 } & $3.350 \pm 2.840$ & $0.290 \pm 0.270$ & $66.710 \pm 70.600$ & $30.150 \pm 20.710$ & $26.190 \pm 10.720$ & $4.730 \pm 4.720$ & $0.496 \pm 0.165$ & $36.190 \pm 35.650$ & $873.000 \pm 1023.420$ \\
\hline & $1.040-8.730$ & $0.083-0.791$ & $6.380-191.750$ & $9.030-61.030$ & $14.280-38.420$ & $0.490-12.510$ & $0.360-0.680$ & $1.200-87.400$ & $151.000-2930.000$ \\
\hline \multirow[t]{2}{*}{ S12 } & $1.770 \pm 1.760$ & $0.190 \pm 0.130$ & $30.930 \pm 21.020$ & $16.970 \pm 12.340$ & $33.520 \pm 11.070$ & $1.910 \pm 2.610$ & $0.450 \pm 0.063$ & $38.710 \pm 33.120$ & $822.800 \pm 873.9000$ \\
\hline & $0.460-4.770$ & $0.040-0.390$ & $5.590-48.250$ & $2.030-33.520$ & $10.41-35.290$ & $0.050-6.500$ & $0.400-0.490$ & $2.000-90.200$ & $120.000-2285.000$ \\
\hline \multirow[t]{2}{*}{ S13 } & $3.830 \pm 4.420$ & $0.360 \pm 0.510$ & $36.870 \pm 37.920$ & $14.270 \pm 8.180$ & $24.220 \pm 10.710$ & $4.002 \pm 2.620$ & $0.570 \pm 0.390$ & $24.980 \pm 15.590$ & $406.000 \pm 276.360$ \\
\hline & $0.380-9.470$ & $0.010-1.270$ & $6.560-94.160$ & $0.610-22.500$ & $10.770-37.680$ & $0.720-7.720$ & $0.290-0.840$ & $6.700-43.440$ & $111.000-684.000$ \\
\hline \multirow[t]{2}{*}{ S14 } & $3.270 \pm 3.020$ & $0.230 \pm 0.250$ & $24.540 \pm 19.500$ & $15.690 \pm 10.590$ & $23.950 \pm 13.510$ & $2.170 \pm 2.060$ & $0.290 \pm 0.010$ & $21.820 \pm 18.530$ & $970.600 \pm 1128.560$ \\
\hline & $0.620-7.750$ & $0.040-0.650$ & $6.620-53.670$ & $2.540-30.920$ & $8.930-39.190$ & $0.500-5.170$ & $0.280-0.300$ & $1.000-42.800$ & $130.000-2850.000$ \\
\hline \multirow[t]{2}{*}{ S15 } & $2.030 \pm 1.750$ & $0.120 \pm 0.090$ & $45.070 \pm 29.070$ & $16.600 \pm 4.270$ & $17.110 \pm 9.940$ & $3.510 \pm 3.200$ & $0.040 \pm$ (n.a.) & $51.360 \pm 58.110$ & $1264.000 \pm 1108.030$ \\
\hline & $0.370-4.980$ & $0.006-0.202$ & $7.160-73.750$ & $12.740-21.670$ & $4.450-28.610$ & $0.710-6.470$ & $0.040-0.040$ & $8.600-151.200$ & $139.000-2545.000$ \\
\hline \multirow[t]{2}{*}{ S16 } & $1.640 \pm 0.660$ & $0.200 \pm 0.110$ & $35.380 \pm 26.260$ & $19.860 \pm 18.360$ & $20.250 \pm 8.650$ & $3.810 \pm 2.460$ & $0.540 \pm 0.110$ & $24.040 \pm 17.060$ & $982.170 \pm 1440.180$ \\
\hline & $0.690-2.430$ & $0.020-0.320$ & $7.660-67.640$ & $2.530-55.270$ & $10.790-32.080$ & $0.840-6.990$ & $0.460-0.610$ & $1.800-44.850$ & $127.000-3880.000$ \\
\hline \multirow[t]{2}{*}{ S17 } & $2.630 \pm 2.470$ & $0.280 \pm 0.180$ & $5.380 \pm 4.390$ & $9.330 \pm 2.840$ & $10.210 \pm 2.810$ & $6.300 \pm 4.030$ & $0.400 \pm 0.220$ & $281.870 \pm 545.060$ & $634.670 \pm 627.270$ \\
\hline & $0.180-6.200$ & $0.010-0.520$ & $0.120-11.630$ & $6.890-14.800$ & $7.700-14.980$ & $1.290-12.440$ & $0.210-0.640$ & $20.400-1388.000$ & $9.000-1335.000$ \\
\hline
\end{tabular}

polluted a few sites, viz. S1, S5, S9, S11, S17, during preand post-monsoon season. The higher concentration of $\mathrm{Pb}$ $(8.350-24.9000 \mu \mathrm{g} / \mathrm{L})$ was most probably due the anthropogenic activity. The temporal-spatial variation in metal distribution illustrated combined impacts from industrial wastage and natural (leaching and weathering) activities factors.

\section{Comparing the distribution of trace elements across Mahanadi River and its tributaries}

The spatial distribution of metals in Mahanadi River was found higher for $\mathrm{Cr}, \mathrm{Cu}, \mathrm{Ni}, \mathrm{Pb}$, and $\mathrm{Fe}$, except that these metals other metals were found within the range recommended by WHO and BIS. The pollution from Fe was found at all three sites (S1, S11, and S17) of the main river during all season, indicated that the metal originated from the discharge of industrial effluents nearby the sites. The $\mathrm{Cr}$ and $\mathrm{Ni}$ concentrations were found higher during post-monsoon, whereas $\mathrm{Cr}$ concentration found higher during pre-monsoon season also. This may be due to anthropogenic and geogenic activities, whereas $\mathrm{Cu}$ is the least dominating and is found only one site (S11) during post-monsoon. This could be led due to dust storm. The dust containing malachite can be easily dissolved in water as the solubility product of $\mathrm{Cu}$ $(\mathrm{OH})_{2}$ and $\mathrm{CuCO}_{3}$ is usually high under normal condition. In contrast the main river, tributaries show the minimum number of metal pollution than main river sites. The largest tributary Seonath with their sub-tributaries was found higher concentration for $\mathrm{Cr}, \mathrm{Ni}, \mathrm{Pb}$, and $\mathrm{Fe}$. The maximum number of tributary sites S3-S7 was polluted with Fe during monsoon and post-monsoon season while for $\mathrm{Ni}$ it was found only post-monsoon season. The metal concentration of $\mathrm{Cr}$

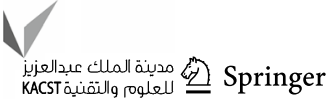


Table 3 WQ hotspots in River Mahanadi and tributaries

\begin{tabular}{|c|c|c|c|c|c|c|c|c|c|c|c|c|c|c|c|c|c|}
\hline Site no & $\mathrm{S} 1$ & $\mathrm{~S} 2$ & S3 & $\mathrm{S} 4$ & S5 & S6 & S7 & S8 & S9 & S10 & $\mathrm{S} 11$ & S12 & S13 & S14 & S15 & S16 & S17 \\
\hline \multicolumn{18}{|c|}{ September, 2011} \\
\hline $\mathrm{Cr}\left(\mu \mathrm{g} \mathrm{L}^{-1}\right)$ & - & - & - & - & 59.25 & - & - & - & 52.75 & - & 191.75 & - & - & - & 72.50 & 61.75 & - \\
\hline $\mathrm{Cu}\left(\mu \mathrm{g} \mathrm{L}^{-1}\right)$ & - & - & - & - & - & - & - & - & - & - & 61.03 & - & - & - & - & - & - \\
\hline $\mathrm{Pb}\left(\mu \mathrm{g} \mathrm{L}^{-1}\right)$ & - & - & - & - & - & - & - & - & - & - & - & - & - & - & - & - & 12.44 \\
\hline $\mathrm{Ni}\left(\mu \mathrm{g} \mathrm{L}^{-1}\right)$ & - & - & - & - & - & - & - & - & - & - & - & - & - & - & - & - & - \\
\hline $\mathrm{Fe}\left(\mu \mathrm{g} \mathrm{L}^{-1}\right)$ & 2300 & - & 1261 & 1432 & 1513 & 2605 & 1197 & 2730 & 1937 & 1964 & 2930 & 2285 & - & 2850 & 2545 & 3880 & 1168 \\
\hline \multicolumn{18}{|c|}{ February, 2012} \\
\hline $\mathrm{Cr}\left(\mu \mathrm{g} \mathrm{L}^{-1}\right)$ & - & - & - & - & - & - & - & - & - & - & - & - & - & - & - & - & - \\
\hline $\mathrm{Cu}\left(\mu \mathrm{g} \mathrm{L}^{-1}\right)$ & - & - & - & - & - & - & - & 53.45 & - & - & - & - & - & - & - & 55.27 & - \\
\hline $\mathrm{Pb}\left(\mu \mathrm{g} \mathrm{L}^{-1}\right)$ & - & - & - & - & - & - & - & - & - & - & - & - & - & - & - & - & - \\
\hline $\mathrm{Ni}\left(\mu \mathrm{g} \mathrm{L}^{-1}\right)$ & - & - & 49.61 & - & - & - & - & 21.33 & - & - & 27.3 & - & - & - & - & - & - \\
\hline $\mathrm{Fe}\left(\mu \mathrm{g} \mathrm{L}^{-1}\right)$ & - & - & - & - & - & - & - & 611 & - & 508 & 478 & - & - & - & - & - & 1335 \\
\hline \multicolumn{18}{|l|}{ June, 2012} \\
\hline $\mathrm{Cr}\left(\mu \mathrm{g} \mathrm{L}^{-1}\right)$ & - & - & - & - & - & - & - & - & - & - & 105.4 & - & 94.16 & - & 73.75 & 67.64 & - \\
\hline $\mathrm{Cu}\left(\mu \mathrm{g} \mathrm{L}^{-1}\right)$ & - & - & - & - & - & - & - & - & - & - & - & - & - & - & - & - & - \\
\hline $\mathrm{Pb}\left(\mu \mathrm{g} \mathrm{L}^{-1}\right)$ & - & - & - & - & - & - & - & - & - & - & - & - & - & - & - & - & - \\
\hline $\mathrm{Ni}\left(\mu \mathrm{g} \mathrm{L}^{-1}\right)$ & - & - & - & - & - & - & - & - & - & 41.0 & 34.58 & - & 29.0 & - & - & - & - \\
\hline $\mathrm{Fe}\left(\mu \mathrm{g} \mathrm{L}^{-1}\right)$ & - & - & - & - & - & - & - & - & - & 828 & 557 & - & 673 & - & 2367 & 604 & - \\
\hline \multicolumn{18}{|c|}{ October, 2012} \\
\hline $\mathrm{Cr}\left(\mu \mathrm{g} \mathrm{L}^{-1}\right)$ & - & - & - & - & - & - & - & 58.52 & - & - & 51.08 & - & 57.1 & 53.67 & - & - & - \\
\hline $\mathrm{Cu}\left(\mu \mathrm{g} \mathrm{L}^{-1}\right)$ & - & - & - & - & - & - & - & - & - & - & - & - & - & - & - & - & - \\
\hline $\mathrm{Pb}\left(\mu \mathrm{g} \mathrm{L}^{-1}\right)$ & 10.45 & - & - & - & 15.35 & - & - & - & 24.9 & - & 12.51 & - & - & - & - & - & - \\
\hline $\mathrm{Ni}\left(\mu \mathrm{g} \mathrm{L}^{-1}\right)$ & 27.63 & 24.75 & 27.67 & 26.17 & 26.1 & 27.38 & 23.47 & 31.71 & 30.22 & - & - & 31.85 & 37.68 & 30.53 & 28.61 & 32.08 & - \\
\hline $\mathrm{Fe}\left(\mu \mathrm{g} \mathrm{L}^{-1}\right)$ & 616 & 535 & 635 & 704 & 541 & 441 & 477 & 643 & 595 & 533 & 431 & 547 & 684 & 518 & 626 & 720 & 1104 \\
\hline \multicolumn{18}{|l|}{ March, 2013} \\
\hline $\mathrm{Cr}\left(\mu \mathrm{g} \mathrm{L}^{-1}\right)$ & - & - & - & - & - & - & - & - & - & - & - & - & - & - & - & - & - \\
\hline $\mathrm{Cu}\left(\mu \mathrm{g} \mathrm{L}^{-1}\right)$ & - & - & - & - & - & - & - & - & - & - & - & - & - & - & - & - & - \\
\hline $\mathrm{Pb}\left(\mu \mathrm{g} \mathrm{L}^{-1}\right)$ & - & - & - & - & - & - & - & - & - & - & - & - & - & - & - & - & - \\
\hline $\mathrm{Ni}\left(\mu \mathrm{g} \mathrm{L}^{-1}\right)$ & - & - & - & - & - & - & - & - & - & - & - & - & - & - & - & - & - \\
\hline $\mathrm{Fe}\left(\mu \mathrm{g} \mathrm{L}^{-1}\right)$ & - & - & - & - & - & - & - & - & - & - & - & - & - & - & - & - & - \\
\hline \multicolumn{18}{|l|}{ August, 2013} \\
\hline $\mathrm{Cr}\left(\mu \mathrm{g} \mathrm{L}^{-1}\right)$ & - & - & - & - & - & - & - & - & - & - & - & - & - & - & - & - & - \\
\hline $\mathrm{Cu}\left(\mu \mathrm{g} \mathrm{L}^{-1}\right)$ & - & - & - & - & - & - & - & - & - & - & - & - & - & - & - & - & - \\
\hline $\mathrm{Pb}\left(\mu \mathrm{g} \mathrm{L}^{-1}\right)$ & - & - & - & - & - & - & - & - & 15.48 & - & - & - & - & - & - & - & - \\
\hline $\mathrm{Ni}\left(\mu \mathrm{g} \mathrm{L}^{-1}\right)$ & - & - & - & - & - & - & - & - & - & - & - & - & - & - & - & - & - \\
\hline $\mathrm{Fe}\left(\mu \mathrm{g} \mathrm{L}^{-1}\right)$ & - & 33 & 556 & 573 & 688 & 625 & - & 750 & 37 & 811 & 691 & 92 & 42 & 1167 & 647 & 42 & - \\
\hline
\end{tabular}

and $\mathrm{Pb}$ was found at the same site $\mathrm{S} 5$ during post-monsoon season (Cr was on September 2011 and $\mathrm{Pb}$ was on October 2012). Other tributaries of main river like Pairi (S2), Jonk (S8), Mand (S12), Ib (S13), Ong (S14), and Tel (S15, S16) were also found maximum Fe concentration for all sites during both season monsoon and post-monsoon season. The metals $\mathrm{Cr}, \mathrm{Cu}, \mathrm{Ni}$, and $\mathrm{Pb}$ also polluted these tributaries at some sites but not found to do so in combination at any site. The higher concentration of metals in river and tributaries was due to anthropogenic and geogenic activities.
On comparing the concentration of main river water and tributaries, the larger number of metals polluted the river sites. In contrast, the tributaries show lesser number of metals and a minimum number of sites were polluted by the metals. Only Fe was the metal that pollutes all sites of main river and tributaries. The metals $\mathrm{As}, \mathrm{Cd}, \mathrm{Hg}, \mathrm{Zn}$ were found within the limit prescribed by WHO and BIS. This may be attributed due to adsorption of metals on to the suspended particles and dilution of contaminant. The overall concentration of metals was found lower than that from earlier studies. 
Table 4 Seasonal variation in heavy metal concentrations in water samples of Mahanadi River

\begin{tabular}{|c|c|c|c|c|c|c|c|c|c|c|c|c|}
\hline \multirow[t]{2}{*}{ Metals } & \multicolumn{4}{|c|}{ Pre-monsoon } & \multicolumn{4}{|c|}{ Monsoon } & \multicolumn{4}{|c|}{ Post-monsoon } \\
\hline & Min & Max & Mean & SD & Min & Max & Mean & SD & Min & Max & Mean & SDv \\
\hline As & 0.180 & 8.730 & 3.041 & 3.107 & 0.380 & 6.080 & 2.553 & 1.732 & 1.270 & 9.470 & 2.824 & 2.429 \\
\hline $\mathrm{Cd}$ & 0.004 & 1.268 & 0.256 & 0.336 & 0.056 & 0.438 & 0.163 & 0.098 & 0.013 & 0.420 & 0.207 & 0.095 \\
\hline $\mathrm{Cr}$ & 2.070 & 39.570 & 11.585 & 9.694 & 0.120 & 105.410 & 33.420 & 27.072 & 4.500 & 191.750 & 42.995 & 32.173 \\
\hline $\mathrm{Cu}$ & 1.730 & 53.450 & 15.521 & 15.293 & 6.890 & 39.000 & 18.886 & 7.814 & 7.320 & 61.030 & 17.846 & 10.204 \\
\hline $\mathrm{Ni}$ & 4.450 & 39.190 & 22.254 & 11.965 & 9.570 & 41.000 & 19.461 & 7.355 & 7.700 & 37.680 & 26.275 & 7.172 \\
\hline $\mathrm{Pb}$ & 0.050 & 8.350 & 1.705 & 1.859 & 0.490 & 15.480 & 4.381 & 3.445 & 0.060 & 24.900 & 5.999 & 5.654 \\
\hline $\mathrm{Hg}$ & 0.290 & 0.460 & 0.374 & 0.071 & 0.040 & 0.840 & 0.343 & 0.223 & 0.640 & 0.640 & 0.640 & (n.a) \\
\hline $\mathrm{Zn}$ & 0.600 & 387.500 & 46.961 & 89.329 & 3.900 & 327.600 & 50.216 & 80.099 & 19.398 & 383.634 & 55.815 & 66.164 \\
\hline $\mathrm{Fe}$ & 9.000 & 151.000 & 268.368 & 300.290 & 82.000 & 2367.000 & 661.522 & 448.668 & 210.000 & 3880.000 & 1308.152 & 962.032 \\
\hline
\end{tabular}

All numerical values are represented in $\mathrm{mg} . \mathrm{L}^{-1}$

\section{Contamination factor (CF) analysis}

For water samples, we defined the contamination factor as the ratio of the average concentration of each metal in the surface water divided by the average background concentration value of the same metal.

$\mathrm{CF}=\frac{C_{n}}{C_{\mathrm{b}}}$

where $\mathrm{C}_{n}$ is the concentration of dissolved metal whose identification is specified by $n$ and $C_{\mathrm{b}}$ is the background concentration of that specific metal. Such comparison with background concentrations can be made at both, local and global scales. The world river average concentration of dissolved metals was used as the representative global background concentration (Li 2000; Kowalski et al. 2007). For local background, Rajim, an upstream station in Mahanadi, was chosen to serve the purpose. In view of Eq. 1, one can define $\mathrm{CF}>1$ as contaminated and $\mathrm{CF}<1$ as non-contaminated with respect to background values.

The calculated values of the different type of CFs for all the nine metals found in the Mahanadi basin with respect to global and local background values are shown in Fig. 4a-i.

In the Mahanadi basin, high local and global CF ratio for zinc (28-402), lead (19-134), chromium (5-66), and lead
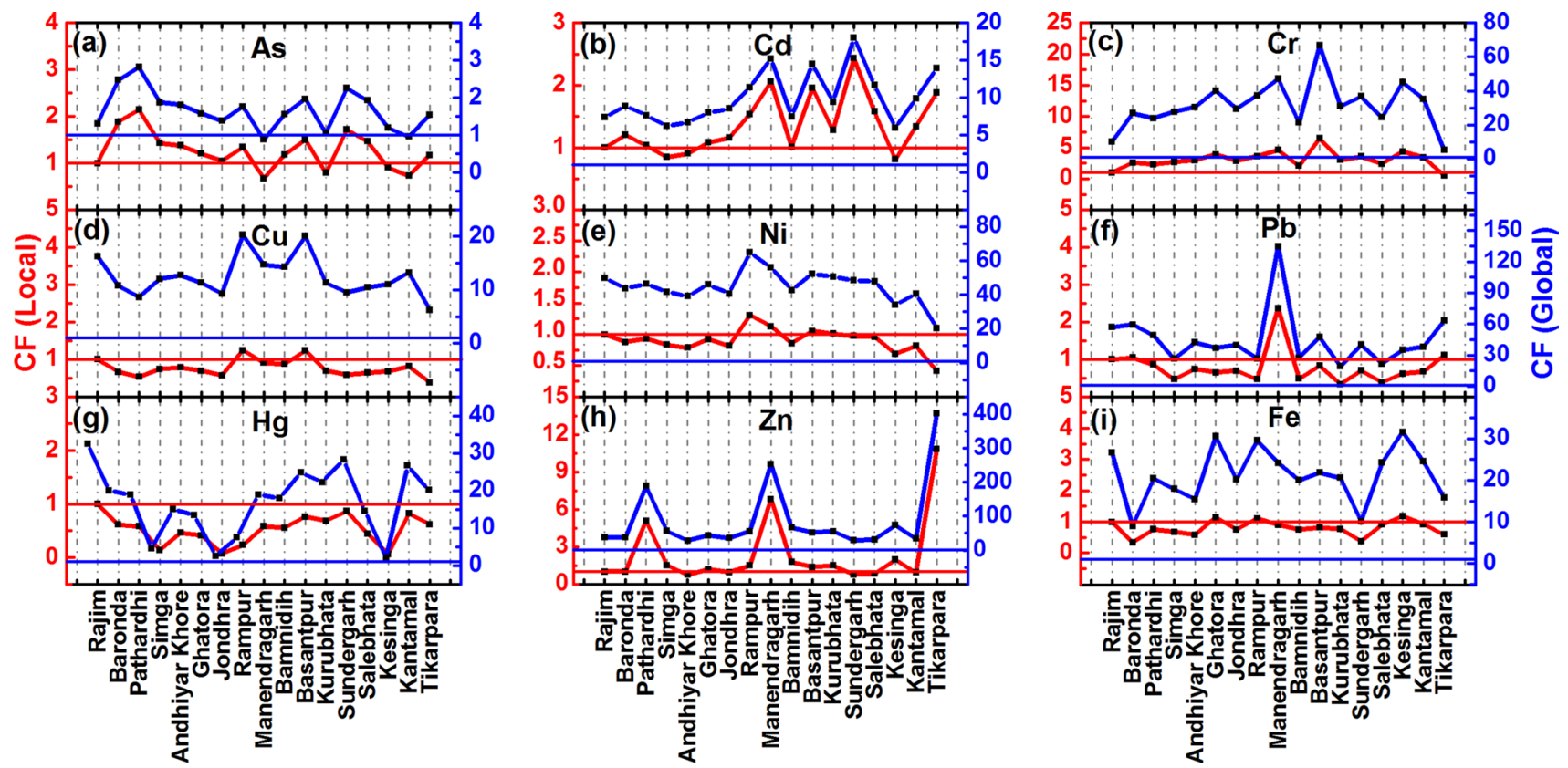

Fig. 4 Contamination factor of the dissolved trace metals of Mahanadi River and its tributaries with respect to local as well as global background values 
(19-63) is found with respect to the global average values. Other metals, viz. copper, iron and mercury, are also higher to some extent. The contamination value of $\mathrm{Cr}$ and $\mathrm{Cu}$ is found higher at S11 during monsoon season due to anthropogenic and geogenic sources. However, the other metals like iron and zinc are found higher at stations S11, S16 while lead is found higher at station $S$ 9, which may be due to anthropogenic sources. This analysis suggests that both municipal and industrial wastes contribute to the most of the metals found in river.

\section{Principal component analysis and correlation analysis}

Principal component analysis is one of the widely used statistical procedures for data reduction and further enabling the visualization of patterns in large datasets of river monitoring stations. By reducing the number of variables to smaller indices (i.e., principal components), it becomes easier to investigate the association of different sample sites and assess the major sources of trace metals in the whole river system. The first three components were chosen as their eigenvalues exceeded the unity, which is a very commonly employed threshold. The first three components accounted for a total variance of $70.15 \%$, of which the first, second, and third components had a contribution of $29.12 \%, 23.45 \%$, and $17.58 \%$, respectively. The biplot obtained from PCA analysis reveals the relationships between metal groups in the space for the first two components (Fig. 5). It is clear that $\mathrm{Ni}, \mathrm{Cr}, \mathrm{Cu}$, and $\mathrm{Fe}$ have similar heavy loadings for principal component 1 , while $\mathrm{Hg}, \mathrm{Pb}$, and $\mathrm{Cd}$ have similar heavy loadings for principal component 2. Further, the distance between the labeled metals and origin in the biplot shows that the categories $\mathrm{Ni}, \mathrm{Cu}, \mathrm{Cr}$, and $\mathrm{Pb}, \mathrm{Cd}, \mathrm{Hg}$ distinguish more than $\mathrm{Fe}, \mathrm{Zn}$, and As. It also indicates that $\mathrm{Ni}, \mathrm{Cr}$, and

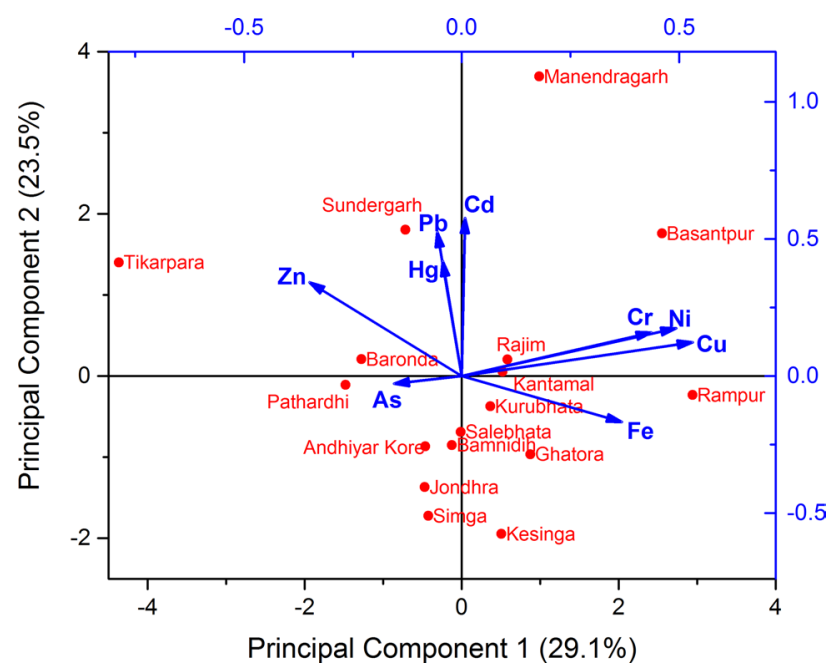

Fig. 5 PCA loading plot for nine trace elements in the surface water of the Mahanadi River

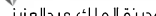

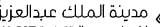
KACST Ka
$\mathrm{Cu}$ are found in higher concentrations, especially at S8 and S11 (Table 3). A clear distinction being made here can be related to the difference in sources of their origin. Though iron concentration was fairly high throughout Mahanadi River basin, some WQ stations, viz. S8, S6 and S15, were found highly polluted with it. Among all metals, only Zn was found in high concentrations at S17. A low angular gradient between $\mathrm{S} 3$ and As with respect to first principal component indicates its highest availability at the WQ site. It may be due to anthropogenic activities in nearby areas.

It is interesting to note that $\mathrm{S} 17$, being a downstream station in our study, in contrast to previous reports (Sundaray et al. 2009, 2012), has been found fairly less polluted with studied metals (except $\mathrm{Zn}$ ) than other WQ stations. This can be correlated with the water storage and its releasing operations of Hirakud dam. Hirakud dam controls the flow of water in the Mahanadi River during monsoon season. The dam regulates the flow of Mahanadi River during monsoon season. The Hirakud dam largely contributes to the dilution and assimilation of trace metals due to precipitation and wetland activity which is naturally present in large dams. Some of the primary industrial uses of Hirakud dam water are associated with mineral processing, coal-fired thermal power plants, and agricultural purposes. There are also many industries related to steel, aluminum, power, sponge iron, etc. in the upstream of Hirakud Dam alongside the reservoir. The effluent and run-off from mining, farming, industries, and irrigation have affected the physico-chemical properties of river water. S17 is the nearest station of Hirakud dam where the concentration of lead and iron was found greater than acceptable limit as compared to other trace elements, which may be due to anthropogenic activities.

To further correlate the metal-metal relationships in river water and soil sediments, the $\mathrm{K}-\mathrm{S}$ test was performed on average values of metals corresponding to each station (from Table 2). It suggested the normality among datasets cannot be ignored. The Pearson's correlation coefficient $(r)$ is used to determine the inter-relationship among different elements. The calculated correlation coefficient corresponds to the numerical measure of the relationship between two and more random variables. A significant positive correlation was observed between (1) $\mathrm{Cu}$ and $\mathrm{Cr}(r>0.5)$, (2) $\mathrm{Ni}$ and $\mathrm{Cu}$ $(r>0.70)$ and (3) $\mathrm{Pb}$ and $\mathrm{Zn}(0.58)$. It could be due to their similar source of geogenic origin and mobility in the region. For other metal-metal combinations, poor correlations were observed $(r<0.5)$. Note that a WQ site-specific claim of these points can be matched with PCA results, which are well consistent with each other. The results indicate large inputs possibly being given from aluminum and thermal power plants at Hirakud dam, charge chrome industry, and power plant at Chowdwar. In addition, the paper industry in Jagatpur and other two operational fertilizer plants in Paradeep discharge effluent directly into Mahanadi River. Its upper stretches at Bhilai and Durg districts have steel 
plant and an Urla iron and steel complex, respectively. There are also some operational cement producing plants near to Andhiyar Kore in Durg and Raipur districts.

\section{Conclusions}

This is one of the first systematic studies of the distributions, concentrations, and possible sources of selected elements in the surface water of the Mahanadi River along with its all tributaries. The concerns exist over the concentrations of $\mathrm{Fe}, \mathrm{Cr}, \mathrm{Cu}, \mathrm{Pb}$, and $\mathrm{Ni}$ at some sites. This may be due to various anthropogenic activities like urbanization, industrialization, mining activities, and human activities. Contrarily, As, $\mathrm{Cd}, \mathrm{Hg}$, and $\mathrm{Zn}$ were found well within the acceptable limit prescribed by WHO and BIS. The contamination ratio indicated that comparatively higher values for $\mathrm{Fe}, \mathrm{Cr}, \mathrm{Cu}$, $\mathrm{Pb}$, and $\mathrm{Ni}$ are observed in some polluted sites. The statistical analysis suggested that high loading of the metals seems to have stemmed out from anthropogenic and geogenic activities. Among these, lead and copper most probably have an anthropogenic origin. On the other hand, copper nickel and chromium might have both anthropogenic origin and geogenic origin. The statistical analysis points toward various industrial wastes and municipal wastes as primary contributing factors for most of the excess dissolved metals in the Mahanadi River. It is clear from our studies that the metal concentrations in river water and its tributaries might increase with time that could be responsible for various diseases on human health and aquatic animals.

Acknowledgements Authors are thankful to Late Dr. Roop Narain, Research officer (Retd. Scientist), Central Water Commission, Delhi, for his critical suggestions and fruitful discussions. Dr Jakir Hussain is grateful to Arati Dubey for data analysis and assist in manuscript preparation.

Funding The work was supported by Central Water Commission, India. AS acknowledges the FTYS scheme (sanction order no. 3063/ CST/FTYS/2019), MPCST, Madhya Pradesh, India, and UGC-BSR Research Start-Up-Grant F.30-420/2018(BSR), University Grants Commission, India.

\section{Compliance with ethical standards}

Conflict of interest The authors declare no conflict of interest.

Open Access This article is licensed under a Creative Commons Attribution 4.0 International License, which permits use, sharing, adaptation, distribution and reproduction in any medium or format, as long as you give appropriate credit to the original author(s) and the source, provide a link to the Creative Commons licence, and indicate if changes were made. The images or other third party material in this article are included in the article's Creative Commons licence, unless indicated otherwise in a credit line to the material. If material is not included in the article's Creative Commons licence and your intended use is not permitted by statutory regulation or exceeds the permitted use, you will need to obtain permission directly from the copyright holder. To view a copy of this licence, visit http://creativecommons.org/licenses/by/4.0/.

\section{References}

Asokan SM, Dutta D (2008) Analysis of water resources in the Mahanadi River Basin, India under projected climate conditions. Hydrol Process 22:3589-3603. https://doi.org/10.1002/hyp.6962

Bem H, Gallorini M, Rizzio E, Krzeminska M (2003) Comparative studies on the concentrations of some elements in the urban air particulate matter in Lodz City of Poland and in Milan, Italy. Environ Int 29:423-428. https://doi.org/10.1016/S0160 $-4120(02) 00190-3$

Bureau of Indian Standard (Ed) (2012) Specification for drinking water, Indian Standard Institution. Bureau of India Standards (BIS) 10500, New Delhi, pp 1-5

Chakrapani GJ, Subramanian V (1990) Preliminary studies on the geochemistry of the Mahanadi river basin, India. Chem Geol $81: 241-253$

Jain SK, Agarwal PK, Singh VP (2007) Mahanadi, Subernarekha and Brahmani basins. In: Hydrology and Water Resources of India. Springer, pp 597-639

Khadse GK, Patni PM, Kelkar PS, Devotta S (2008) Qualitative evaluation of Kanhan river and its tributaries flowing over central Indian plateau. Environ Monit Assess 147:83-92. https://doi. org/10.1007/s10661-007-0100-x

Kowalski A, Siepak M, Boszke L (2007) Mercury contamination of surface and ground waters of Poznań, Poland. Pol J Environ Stud $16: 67$

Li Y-H (2000) A compendium of geochemistry, from solar nebula to the human brain. Princeton University Press, Princeton

Mohanty D, Samanta L (2016) Multivariate analysis of potential biomarkers of oxidative stress in Notopterus notopterus tissues from Mahanadi River as a function of concentration of heavy metals. Chemosphere 155:28-38. https://doi.org/10.1016/j.chemospher e.2016.04.035

Olsen RL, Chappell RW, Loftis JC (2012) Water quality sample collection, data treatment and results presentation for principal components analysis-literature review and Illinois River watershed case study. Water Res 46:3110-3122. https://doi.org/10.1016/j. watres.2012.03.028

Ouyang Y (2005) Evaluation of river water quality monitoring stations by principal component analysis. Water Res 39:2621-2635. https ://doi.org/10.1016/j.watres.2005.04.024

Shrestha S, Kazama F (2007) Assessment of surface water quality using multivariate statistical techniques: a case study of the Fuji river basin, Japan. Environ Model Softw 22:464-475. https://doi. org/10.1016/j.envsoft.2006.02.001

Singh KP, Mohan D, Singh VK, Malik A (2005) Studies on distribution and fractionation of heavy metals in Gomti river sediments-a tributary of the Ganges, India. J Hydrol 312:14-27. https://doi. org/10.1016/j.jhydrol.2005.01.021

Sundaray SK, Panda UC, Nayak BB, Bhatta D (2006) Multivariate statistical techniques for the evaluation of spatial and temporal variations in water quality of the Mahanadi river-estuarine system (India) — a case study. Environ Geochem Health 28:317-330. https ://doi.org/10.1007/s10653-005-9001-5

Sundaray SK, Nayak BB, Bhatta D (2009) Environmental studies on river water quality with reference to suitability for agricultural purposes: Mahanadi river estuarine system, India - a case study. Environ Monit Assess 155:227-243. https://doi.org/10.1007/ s10661-008-0431-2

Sundaray SK, Nayak BB, Kanungo TK, Bhatta D (2012) Dynamics and quantification of dissolved heavy metals in the Mahanadi river

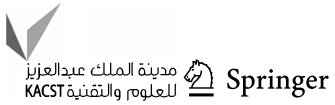


estuarine system, India. Environ Monit Assess 184:1157-1179. https://doi.org/10.1007/s10661-011-2030-x

World Health Organization (2011) Guidelines for drinking-water quality. World Health Organization, Geneva
Publisher's Note Springer Nature remains neutral with regard to jurisdictional claims in published maps and institutional affiliations. 